\title{
E-Book Usage in Teaching Science: The Perspectives of Science Teachers in Secondary Schools in Selangor
}

\author{
Johan@Eddy Luaran ${ }^{1 *}$, Kamarol Baharen Mohd Rom², \\ Fazyudi Ahmad Nadzri ${ }^{3}$ and Jasmine Jain ${ }^{4}$ \\ ${ }^{1,2,3}$ Faculty of Education, Universiti Teknologi MARA, Selangor, Malaysia \\ ${ }^{4}$ School of Education, Taylor's University, Lakeside Campus, Subang Jaya, Malaysia \\ *johaneddy@salam.uitm.edu.my
}

Published online: 27 December 2016

To cite this article: Luaran, J. @ E., Kamarol Baharen Mohd Rom, Fazyudi Ahmad Nadzri and Jasmine Jain. 2016. E-book usage in teaching Science: The perspectives of Science teachers in secondary schools in Selangor. Malaysian Journal of Distance Education 18(1): 13-27. http://dx.doi.org/10.21315/mjde2016.18.1.2

To link to this article: http://dx.doi.org/10.21315/mjde2016.18.1.2

\begin{abstract}
E-book is one of the products of technology that have benefited many educators all around the world. Previous studies have shown that e-book brings positive effects on students' academic achievements. Due to this scenario, this study aims to investigate the preferences of teachers in the use of e-book in teaching and learning. It also identifies the impacts of using e-book in teaching and learning and determines the challenges of using e-book. Forty eight science teachers from selected schools in Selangor were the respondents for this study. Quantitative approach was employed with questionnaires used as the instrument. The findings indicated that most of the respondents had positive perceptions on the use of e-book in classrooms and were willing to overcome the challenges that they were facing.
\end{abstract}

Keywords: Information Communication Technology, classroom, Science subject

\section{Introduction}

E-book or electronic book is a type of digital book that contains a lot of multimedia programs. Its user claimed that it was easy to read and get information from this technology (Jiménez, Pellicer and Yepes, 2000). There is a lot of published research describing the types of e-book. Mohd Fakhrulzaman (2005) stated that e-books can be classified according to 
their perspectives, types of reader, contents and types of delivery. In the perspective of types of reader, there are two types; hardware-based reader and software-based reader. For hardware-based reader, a custom made devise to read e-book such as Franklin e-BookMan and GermStar are used. For software-based reader, users can choose to read e-book format such as Adobe Acrobat Reader or Microsoft Internet Explorer. In content perspective, e-book is classified based on the way it is presented to the user. The difference between a traditional book and an e-book is the latter's capabilities in embedding multimedia elements in the e-book. Based on content, there are three families of e-book; static, partly multimedia and fully multimedia. The next is the type of delivery. According to Wilson, Jaichenco and Martínez-Cuitiño (2000), an extended book is one of the means used to deliver an e-book to users. An extended book refers to a book that uses a CD-ROM as a medium of delivery data to users. Other type of delivery is the web book. Web book refers to the book that is available online like Freebooks, e-Book-to-buy, and Open e-Book. In his analysis of e-book, Mohd Fakhrulzaman (2005) identified six types of web book. They are delivered to users; free of charge, purchased only, read only, borrowed only, downloadable and printed versions. Jane (2009) stated that the other dimensions include the reading of a book in electronic format. Some hardware devices like personal computers are designed to support all kinds of activities so reading e-book in a computer needs a software application that can read the file.

In a study which was carried out to determine e-book concepts, Sobihatun (2002) found that e-book concepts included all the reading materials that were kept in digital form by any kind of software manually. These reading materials include the multimedia programs or integration packages that are in the forms of texts, graphics, sounds, animations and videos and also the way of interaction to the users. Graphics can help users to communicate with many types of information. Animations can help users to present the information efficiently and attract users to object movement and so on. Sounds can show the feedback of something and texts are used to send information, order anything that can understand the users' one way communication tool. Besides, most e-books apply the hypertext concept, which allows users to open pages continuously. Other than that, an e-book is able to link any documents in other websites on the Internet through hyperlink. Study on the features of e-book has now been accepted by people because 
of its technological advances and technology acceptance (Jane, 2009). People are very comfortable with the idea of personal and portable technology as essential accessories. E-books in these devices such as smart phones and iPads are always available and can be used at any time and any place.

Understanding the potential and benefits that e-book possesses in terms of learning, this study aimed to investigate the preferences of teachers in the use of e-book in teaching and learning. Besides that, this study also further probe on the impact of using e-book in teaching and learning. This study was carried out with a motivation to comprehend the different aspects of e-book usage in order to improve practices of teachers.

\section{Research Questions}

The research questions for this study are:

1. What are the teachers' preferences in using e-book for teaching and learning?

2. What are the impacts of using e-book in teaching and learning?

3. What are the challenges of using e-book in teaching and learning?

\section{Research Design}

Table 1 shows the description of the questionnaire consisting of four parts which are part A, B, C and D, used in this study. In addition to the questionnaire, the open ended questions were used to find out the positive and negative impacts of using e-book in classrooms and the challenges of using e-book.

\section{Sample}

The sample in this research were Science teachers in eight secondary schools in Selangor. To qualify as a sample for this research, the respondents must teach Science subjects that include Biology, Chemistry and Physics. Overall, the total number of the samples in this study is 48 Science teachers from four areas which are Shah Alam, Klang, Damansara and Subang, as shown in Table 2. 
Table 1 Descriptions of the research instrument

\begin{tabular}{clc}
\hline Section & \multicolumn{1}{c}{ Description } & $\begin{array}{c}\text { Number of } \\
\text { items }\end{array}$ \\
\hline A & $\begin{array}{l}\text { Collecting demographic data such as gender, age, area of } \\
\text { school, teaching subject and years of teaching experience }\end{array}$ & $5(1-5)$ \\
B & $\begin{array}{l}\text { Focusing on the preference of the teacher in using e-book } \\
\text { in teaching and learning and also the teachers' computer } \\
\text { competencies }\end{array}$ & $10(6-15)$ \\
C & $\begin{array}{l}\text { Focusing on the positive and negative impacts of using } \\
\text { e-book in classrooms }\end{array}$ & $7(16-22)$ \\
D & $\begin{array}{l}\text { Focusing on the challenges of using e-book in teaching } \\
\text { and learning }\end{array}$ & $6(23-28)$ \\
\hline
\end{tabular}

Table 2 Distribution of schools and number of teachers involved

\begin{tabular}{lcc}
\hline Areas of schools & $\begin{array}{c}\text { Number of schools } \\
\text { involved }\end{array}$ & $\begin{array}{c}\text { Number of science } \\
\text { teachers involved }\end{array}$ \\
\hline Shah Alam & 2 & 19 \\
Subang & 2 & 10 \\
Klang & 3 & 16 \\
Damansara & 1 & 3 \\
\hline Total & 8 & 48 \\
\hline
\end{tabular}

\section{Demographic Data}

Based on Table 3, the number of respondents is 48 . Seventy five percent of them are female $(n=36)$ and the remaining $25 \%$ are male $(n=12)$. Most of them are in the ages between 21 and 30 years old $(n=35)$. They are new teachers teaching in their schools. The others are in the ages between 31 and 40 years old and between 41 and 50 years old.

Most or $35 \%$ of the respondents teach Physics. This is followed by Science $29 \%(n=14)$. It can also be found that some teachers teach two subjects like Science and Biology, Science and Chemistry, and Science and Physics. The percentage of teachers with one to five years of teaching experience is $73 \%$ while $19 \%$ of them have 6 to 10 years experience in teaching. Only $2 \%$ of the teachers $(n=1)$ have teaching experience for more than 15 years. 
Table 3 Respondents' Demographic Data

\begin{tabular}{lcc}
\hline & Frequency & Percent $(\%)$ \\
\hline 1. Respondents' Gender & 12 & \\
Male & 36 & 25 \\
Female & 48 & 75 \\
\hline Total & & 100.0 \\
\hline 2. Respondents' Age & 35 & \\
$21-30$ & 8 & 73 \\
$31-40$ & 5 & 17 \\
$41-50$ & 0 & 10 \\
$51-60$ & 48 & 0 \\
\hline Total & & 100.0 \\
\hline
\end{tabular}

3. Subject Taught

Science

$14 \quad 29$

Biology

$6 \quad 13$

Chemistry

$6 \quad 13$

Physics

17

35

Science and Biology

36

Science and Chemistry

2

Science and Physics

12

\begin{tabular}{lcc} 
Science and Physics & 1 & 2 \\
\hline Total & 48 & 100.0 \\
\hline
\end{tabular}

4. Teaching Experience

$1-5$ years

$35 \quad 73$

6-10 years

$9 \quad 19$

11-15 years

$3 \quad 6$

More than 15 years

12

Total

48

100.0

\section{Results and Discussion}

\section{Teachers' Preference in using e-book in Teaching and Learning}

Based on Table 4, it can be found that $79 \%$ of the teachers are familiar with e-book. This is reflected in Table 5 where it can be seen that more than half of the respondents look for teaching aids from the e-book. 
Table 4 Total respondent familiar with e-book

\begin{tabular}{ccc}
\hline Total respondent & Frequency & Percentage (\%) \\
\hline Yes & 38 & 79 \\
No & 10 & 21 \\
\hline Total & 48 & 100 \\
\hline
\end{tabular}

Table 5 The total respondent find the teaching aids from e-book

\begin{tabular}{ccc}
\hline Find teaching aids & Frequency & Percentage $(\%)$ \\
\hline Yes & 27 & 56 \\
No & 6 & 13 \\
Sometime & 15 & 31 \\
\hline Total & 48 & 100 \\
\hline
\end{tabular}

Based on Table 6, it can be found that the majority or $47.9 \%$ of the teachers spent not more than once a week to use e-book for teaching and learning. Only $27.1 \%$ of the teachers being surveyed use e-book for teaching at least once a week. This shows that the teachers use e-book in teaching.

Table 6 Time use e-book for teaching and learning purpose

\begin{tabular}{lcc}
\hline Time use e-book & Frequency & Percentage (\%) \\
\hline Never & 6 & 12.5 \\
Less than once a week & 23 & 47.9 \\
At least once a week & 13 & 27.1 \\
Everyday & 6 & 12.5 \\
\hline Total & 48 & 100 \\
\hline
\end{tabular}

Based on Table 7, most of the respondents (59\%) feel that e-book is necessary in teaching Science and only $6 \%(n=3)$ of respondents feel that e-book is not necessary in teaching the same subject. The remaining $18 \%$ of the respondents are not sure of the necessity of e-book in teaching Science.

Overall, most of the Science teachers being surveyed have direct and indirect knowledge about e-book but not all of them apply their knowledge in teaching and learning. This also means the respondents know the information used in teaching is e-book. This is supported by Jane (2009) who found that 
Table 7 Feel e-book is necessary in teaching Science

\begin{tabular}{ccc}
\hline $\begin{array}{c}\text { Respondent feel e-book is } \\
\text { necessary in teaching Science }\end{array}$ & Frequency & Percentage (\%) \\
\hline Yes & 30 & 59 \\
No & 3 & 6 \\
Unsure & 18 & 35 \\
\hline Total & 48 & 100 \\
\hline
\end{tabular}

although e-book appears in headlines with regular frequency, there is still confusion about what exactly an e-book is that makes it difficult to focus on the real issues. These teachers need some explanations about e-book. Based on Understanding the Basics by Jane (2009), there are different perceptions among people about e-book in the last few years. Before this, people believed that e-book is a handheld device whose main purpose was to look and act like a book but now e-book can be read on your PDA, smart phones and any technology devices. Besides, the teachers do not want to take risk using e-book in class because of other factors that prevent them from doing so. The factors will be revealed in the finding of other research questions. Excellence in teaching can be achieved with good teaching techniques. However, applying the latest techniques does not guarantee excellent teaching or enhancing learning (Anne et al., 1997).

\section{Impacts of e-book to Teachers and Students}

Based on the findings of this research, it is evident that e-book has positive and negative impacts on teachers and students in learning process. Based on Table 8 , two of the five given statements were agreed by the respondents and the other items (item 4, 3 and 5) were undecided. Item 4, which has a mean of 3.44 , is undecided. This shows that the students are more serious in learning if their teachers like to use computer and internet resources in their classrooms. This shows that teacher's attitude in teaching is important to generate interests in the subject among the students. This is possible since the teachers are able to be real persons, who can play some sort of roles, provide resources and tools and include themselves among the resources for which the pupil might discover (Cyril, 1960). This is supported by Afshari et al. (2009), who claimed that teachers are at the center of curriculum 
change and they control the teaching and learning processes. Therefore, they need to prepare young people for the ICT knowledge to acquire and process information (Plomp et al., 1996).

Table 8 Positive and negative impacts of using e-book

\begin{tabular}{clcc}
\hline No & \multicolumn{1}{c}{ Items } & Mean & SD \\
\hline 1 & $\begin{array}{l}\text { Do you think e-book give many benefits in teaching } \\
\text { and learning? }\end{array}$ & 4.21 & 0.54 \\
2 & $\begin{array}{l}\text { Do you agree e-book make your teaching method } \\
\text { more interesting? }\end{array}$ & 4.15 & 0.62 \\
4 & $\begin{array}{l}\text { Do you think students are more serious in learning if } \\
\text { teachers like to use computer and internet resources } \\
\text { in classroom? }\end{array}$ & 3.44 & 1.17 \\
3 & $\begin{array}{l}\text { Using a computer in classroom takes a lot of teaching } \\
\text { time. Do you agree with this statement? }\end{array}$ & 3.33 & 1.02 \\
& $\begin{array}{l}\text { Do you feel e-book is hard to find online and wastes } \\
\text { your time? }\end{array}$ & 2.69 & 1.06 \\
\hline
\end{tabular}

According to Mohd Fakhrulzaman (2005), e-book has the ability to embed multimedia elements. There are three types of e-book based on content: (1) static, (2) partly multimedia and (3) fully multimedia. It depends on teachers to make a topic more interesting to students in classes.

The highest scoring statement in Table 8 is item 1 (mean 4.21) which revealed that e-book gives many benefits in teaching and learning. This statement was supported by the finding reported in Table 7, which shows that more than half of the teachers feel that e-book or any Internet resources are necessary in teaching Science. Aside from that, the second highest scoring statement in this table is item 2, which reveals that e-books make teaching more interesting. This statement was supported by theme $1(35.4 \%)$ in Table 9.

Based on Table 8, items 1 and 2 are about the positive impacts of using e-book. The respondents agreed with both statements. Item 4 receives both positive and negative impacts. The result from content analysis in Table 10 shows that using e-book in classroom causes less attention by the students. Item 3 and item 5 are the negative impacts and both of these items were undecided by the respondents. Based on finding in reported in Table 6, most 
of the teachers use e-book less than once a week for teaching and learning purposes. This shows that the respondents have less experience using e-book in classrooms so they could not decide the items.

Table 9 Content analysis for other positive impacts of using e-book in classrooms

\begin{tabular}{clcc}
\hline No & \multicolumn{1}{c}{ Theme } & Frequency $(n)$ & Percentage $(\%)$ \\
\hline 1 & Learning becomes more interesting & 17 & 35.4 \\
2 & Get extra knowledge & 8 & 16.7 \\
3 & Increase students' attention & 6 & 12.5 \\
4 & Motivate students & 6 & 12.5 \\
5 & Easy to find information & 11 & 22.9 \\
\hline
\end{tabular}

In addition to investigating the other positive and negative impacts, the researcher carried out content analysis for each impact, which are represented in Table 10 and Table 11. Theme 1 in Table 9 reveals that learning becomes more interesting. The accepted reasons of this result are teachers can vary their teaching styles and increase their information on the subject by using e-book. Goktas, Yildirim and Yildirim (2009) stated that teacher's characteristic is also important in implementing a creative teaching style in class. A teacher who is a creative thinker is more likely to use computers in more integrative and transformational ways that are useful and valuable to students instead of ways that promote and support traditional classroom practices (Bielaczyc and Collins, 1999; Carvin, 1999).

Table 10 Content analysis for other negative impacts of using e-book in classrooms

\begin{tabular}{clcc}
\hline No & \multicolumn{1}{c}{ Theme } & Frequency $(n)$ & Percentage $(\%)$ \\
\hline 5 & Less attention by students & 18 & 37.50 \\
3 & Technical problems & 6 & 12.50 \\
4 & Wasting time & 6 & 12.50 \\
1 & Lessons become complicated & 15 & 31.25 \\
2 & No creativity & 3 & 6.25 \\
\hline
\end{tabular}

The second highest is theme 5 which reveals the ease to find information with $22.9 \%$. This shows that the teachers like to use e-book because it is easy to find related information for the topics they teach. This is also depending on their accessibility to the Internet connection. Theme 5 in Table 
10 reveals that e-book can cause less attention by the students and lessons become complicated. The reasons are highlighted because some e-books are too complicated for students and many sources of information referred from the Internet tend to confuse the students. However, these are only the thoughts of teachers who are having negative perceptions on e-book and the Internet. Previous study by Goktas, Yildirim and Yildirim (2009) did not deal with negative impacts of using e-book in teaching. This study indicates contradictory results if compared to the literature on barrier (USDE, 2000) in that 'lack of appropriate course content and instructional programs,' 'lack of time,' and 'lack of appropriate administrative support' are not representing main barriers.

Table 11 Content analysis for other factors that can bring problems in using e-book

\begin{tabular}{clcc}
\hline No & \multicolumn{1}{c}{ Theme } & Frequency $(n)$ & Percentage (\%) \\
\hline 1 & E-book is too advance & 10 & 20.83 \\
2 & E-book is hard to understand & 19 & 39.58 \\
3 & Limited time & 19 & 39.58 \\
\hline
\end{tabular}

\section{Problems in using e-book among teachers}

From the finding of this research, it was found that there are some factors that can cause problems in using e-book. All items in Section D are designed to achieve the research question 3 in this study. Based on Table 12, four out of the five given statements were agreed by the respondents and only one item (item 2) was disagreed. The highest score in Table 12 is item 5 which reveals that printed e-book is costly. E-book commonly contains many pages and this is costly to teachers because they need to download and print the e-book by themselves. In addition, not all e-books are free on the Internet and the purchased e-books are also expensive. This statement is supported by Wilson (2003) who stated that the expensive e-book cost is not reliable with the weakness of its quality control and document available. Two items (item 3 and 4) receive the second highest scoring with the same mean, 4.17. These two items are negative-phrased statements. Item 3 reveals that not all e-books in the web are suitable for teaching and learning. This item was supported by Theme 2 in 11 which states that e-books are hard to understand. This item is also supported by Theme 1 in Table 11 which states that e-books are too advanced. Item 4 reveals not all classrooms have 
computers and Internet connection. This item was supported by Theme 3 in Table 10, which states that technical problems are other negative impacts of using e-book in classrooms. These two items show the characteristics of e-book. This means teachers are totally given problems in teaching and learning process. A study by Goktas, Yildirim and Yildirim (2009) found that crowded classroom, inadequate ICT-related course, lack of computers and lack of teachers' motivation to be among the factors that contribute to negative impacts of using ICT in classrooms. In another study by Salehi and Salehi (2012), it was found that there are three factors preventing teachers from using ICT in classroom. They are insufficient technical support from the school, limited access to the internet and ICT and shortage of class time.

Table 12 Factors that bring problem in using e-book

\begin{tabular}{clcc}
\hline No. & \multicolumn{1}{c}{ Items } & Mean & SD \\
\hline 1 & Internet connection in school is very weak & 3.77 & 1.06 \\
2 & $\begin{array}{l}\text { I have personal problems in using the Internet to } \\
\text { find resources }\end{array}$ & 2.46 & 1.01 \\
3 & $\begin{array}{l}\text { Not all e-books in the web are suitable for teaching } \\
\text { and learning }\end{array}$ & 4.17 & 0.60 \\
4 & $\begin{array}{l}\text { Not all classrooms have computers and Internet } \\
\text { connection }\end{array}$ & 4.17 & 0.91 \\
5 & Printed e-book is costly. & 4.27 & 0.74 \\
\hline
\end{tabular}

Focusing on the analysis of Table 12, four items (item 5, 3, 4, 1) are identified as the external factors that bring problems to teachers in using e-book. The definition of external factor in this study is the outside factors that cause the problems in using e-book. Only item 2 that read 'I have problems in using Internet to find resources' is identified as an internal factor. The definition of internal factor in this study is the inside factors of individual that can cause problems in using e-book. But if teachers perceived ICT or e-book referred in this study as a beneficial tool, compatible with their current activities, easy to use and has observable outcomes, they will demonstrate positive attitudes towards ICT (Afshari et al., 2009).

The finding shows that the respondents disagree with the statement. This proves that the respondents do not have problems in surfing the Internet to find any resources. This is supported by the details of Table 5, where 
more than half of the teachers always find teaching aids from e-book or any internet resources.

In addition to investigate other factors that can bring problems in using e-book, the researcher carried out three themes, listed in Table 11. Theme 2 and Theme 3 achieved the same percentage, 39.58\%. Many respondents wrote in Theme 2 that e-book is hard to understand. This is supported by Table 6, which states that many teachers use e-book for teaching and learning purpose less than once a week. The accepted reason is the teachers do not want to use e-book during teaching and learning process. This is why it is difficult for them to apply e-book in classrooms. This is more related to teacher's attitude in teaching. Theme 3 states that limited time can bring problems in using e-book. When teachers want to find e-book of related topics as a teaching aid, it will consume a lot of time. This is supported by Bauer and Kenton (2005) who stated that students did not have enough time at their computers and teachers needed extra planning time for technology lessons. This action can disturb the teaching process from running smoothly.

\section{Level of Teachers' Computer Knowledge Influence the Use of e-Book in Teaching}

In question 4, the researcher wanted to identify the level of the teachers' computer knowledge that can relate with the first research question, the preference of teacher in using e-book in teaching Science. The result of this study shows that two out of the five given statements were agreed by the respondents, while two items (item 9, 7) were undecided and only item 6 was disagreed. The highest scoring in Table 13 is item 8 which specifically reads 'I feel comfortable using computer in my classroom' which received a mean of 3.98. A possible explanation for this might be that Science teachers are familiar using computer so they are confident using computers during teaching in class. Computer literacy among the teachers is also important in determining the use of e-book in classrooms. In studies by Afshari et al. (2009), and Knezek and Christensen (2000), educators with higher levels of skill, knowledge, and tools would exhibit higher levels of technology integration in the classroom. It was followed by the second highest scoring, item 10 that reads that 'I often integrate computer knowledge in my teaching activities'. Based on the finding (Question 4, Section B of questionnaire), 
most respondents use e-book for teaching and learning purpose and it is used less than once a week. A study by Bauer and Kenton (2005) supported the finding, showing that even if the teachers were educated and skilled with technology, were innovative and adept at overcoming obstacles, they did not integrate technology on a consistent basis as both a teaching and learning tool. However, these findings do not encourage the research question to identify the level of teacher's computer knowledge in the use of e-book in teaching. The researcher identified that the teachers have good computer knowledge but because of some factors, they could not apply it in classrooms.

Table 13 Respondent's computer knowledge

\begin{tabular}{clcc}
\hline No. & \multicolumn{1}{c}{ Items } & Mean & SD \\
\hline 8 & $\begin{array}{l}\text { I feel comfortable using computer in my classroom } \\
9\end{array}$ & 3.98 & 0.70 \\
& $\begin{array}{l}\text { I am very proficient in using a wide variety of } \\
\text { applications in my classroom }\end{array}$ & 3.48 & 0.80 \\
10 & $\begin{array}{l}\text { I often integrate computer knowledge in my } \\
\text { teaching activities }\end{array}$ & 3.60 & 0.68 \\
7 & $\begin{array}{l}\text { I have attempted to use computer in my classroom } \\
\text { but I still require help on a regular basis }\end{array}$ & 3.21 & 1.05 \\
6 & $\begin{array}{l}\text { I have no experience with computer } \\
\text { n }\end{array}$ & 2.00 & 1.26 \\
\hline
\end{tabular}

\section{Conclusion}

The main findings of this study revealed that there are many challenges and limitation that the teachers are having with the use of e-book, despite understanding the vast potential that e-books could offer in leveraging the effectiveness of teaching and learning. From this study, it is clear that the awareness of Science teachers in using e-book for teaching and learning is low. Due to the struggles in operating e-books, teachers find it hard to integrate its use into teaching and learning process, especially when time is limited. The findings infer that more trainings on using technology should be given as part of teachers' professional development courses, in order to help them to become more effective teachers towards nurturing future generation who needs to be technologically literate for the 21 st century workforce. 


\section{References}

Abdullah, A. 2010. The importance of teachers in integrating ICT into Science teaching in intermediate schools in Saudi Arabia: A mixed methods study. http://researchbank. rmit.edu.au/eserv/rmit:12520/Al_Sulaimani.pdf (accessed 15 July 2013).

Anne, T. R., S. C. Deanna, G. T. Barbara and R. T. Elwin. 1997. Reflections on what makes a good teacher. Radiologic Technology. http://jan.ucc.nau.edu/ $\operatorname{sim} / \operatorname{AdjCI} /$ Teaching/Teacher.html (accessed 11 September 2013).

Azelin Mohd Nor, Abd Mutalib Embong, Muhamad Ridhuan Tony Lim Abdullah. 2012. E-book in Malaysia primary schools: The Terengganu chapter. World Academy of Science, Engineering and Technology.

Baek, Y., J. Jung and B. Kim. 2008. What makes teachers use technology in the classroom? Exploring the factors affecting facilitation of technology with a Korean sample. Computers and Education. 50(4):224-234. http://tu2010gerdts.pbworks.com/f/ Literature+Review+\%231.pdf(accessed 25 Sept, 2013). https://doi.org/10.1016/j. compedu.2006.05.002

Bauer, J. and J. Kenton. 2005. Technology integration in the schools: Why it isn't happening. Journal of Technology \& Teacher Education 13:519-526.

Bielaczyc, K. and A. Collins. 1999. Learning communities in classrooms: A reconceptualization of educational practice. In Instructional-design theories and models. A new paradigm of instructional theory, ed. C. Reigeluth, 2: 269-292.

Borchers, J. 1999. Definition: Electronic book. Electronic Book: Definition, Genres, Interaction Design Patterns. http:/hci.rwth-aachen.de/materials/publications/ borchers1999c.pdf (accessed 07 December 2013).

Carvin, A. 1999. Technology professional development for teachers: Overcoming a pedagogical digital divide. The Digital Beat 1(16): 1-5. http://www.benton.org/ DigitalBeat/db093099.html.

Cyril, R. M. 1960. Attitudes affect how educational leadership. http://www.ascd.org/ ASCD/pdf/journals/ed_lead/el_196001_mill.pdf (accessed 18 September 2013).

Explorable.com. Jun 16, 2009. Definition of Science. http://explorable.com/definition-ofscience (accessed 07 December 2013).

Goktas, Y., S. Yildirim and Z. Yildirim. 2009. Main barriers and possible enablers of ICTs integration into pre-service teacher education programs. Educational Technology \& Society 12(1): 193-204. http://www.ifets.info/journals/12_1/15.pdf (accessed 2 September 2013).

Jane, L. 2009. E-books: Understanding the basics. http://www.cdlib.org/services/uxdesign/ docs/2009/e-book_basics_june2009.pdf.

Jiménez, E., E. Pellicer, V. Yepes. 2011. Teaching and learning using a case study: application to a master degree in construction management. Procedia Social and Behavioral Sciences 15: 696-702. https://doi.org/10.1016/j.sbspro.2011.03.167

Knezek, G. and R. Christensen. 2000. Refining best teaching practices for technology integration: KIDS project findings for 1999-2000. Denton, TX: Institute for the Integration of Technology into Teaching and Learning (IITTL). 
Look, D. 2005. Discussion paper: Impact of technology on education for PUSD excellence committee. http://pleasantonusd.net/wp-content/uploads/2012/09/Technology. pdf (accessed 25 September 2013).

Margaret, C. H. and A. B. Melissa. 2009. Data collection methods I Semi - structured interviews and focus group. National Defense Research Institute. http://www. rand.org/content/dam/rand/pubs/technical_reports/2009/RAND_TR718.pdf (accessed 10 December 2013).

Mohd Fakhrulzaman, C. H. 2005. E-book reader: A comparison on perceived usefulness and ease of use. Masters diss. Faculty of Information Technology, Universiti Utara Malaysia (UUM), Sintok.

Mojgan Afshari, Kamariah Abu Bakar, S. L. Wong, Bahaman Abu Samah and S. F. Foo. 2009. Factors effecting teachers use of information and communication technology. International Journal of Instruction 2(1): 77-104. http://www.e-iji. net/dosyalar/iji_2009_1_5.pdf(accessed 1 September 2013).

Nurliyana, O. 2013. Microblogging in school: Students' perception on the use of twitter and its effects on their participation in school. University Technology MARA(UiTM).

Plomp, Tj., A.C.A. ten Brummelhis and R. Rapmund. 1996. Teaching and learning for the future. Report of the Committee on MultiMedia in Teacher Training (COMMITT). Den Haag: SDU.

Salehi, H. and Z. Salehi. 2012. Integration of ICT in language teaching: Challenges and barriers. Proceedings of the 3rd International Conference on e-Education, e-Business, e-Management and e-Learning (IC4E, 2012), IPEDR, 27: 215-219.

Seema Sirpal. 2013. Basic computer concept. Delhi University Computer Centre. http://vfu. bg/en/e-Learning/Computer-Basics--computer_basics2.pdf (accessed December 07 2013).

Sobihatun Nur bt Abdul Salam. 2002. Implementasi konsep ebook di sekolah luar bandar; Satu kajian kes. Masters diss. Faculty of Information Technology, Universiti Utara Malaysia (UUM), Sintok.

Wilson, R. 2003. E-book readers in higher education. Journal of Educational Technology and Society 6(4): 8-17.

Wilson, M., V. Jaichenco and M. Martínez-Cuitiño. 2000. The effects of imageability and grammatical class in synonym judgement in Aphasia. Procedia Social and Behavioral Sciences 61: 62-63. https://doi.org/10.1016/j.sbspro.2012.10.080 